\title{
Timber \\ Structure, Properties, Conversion and Use
}




\title{
Timber \\ Structure, Properties, Conversion and Use
}

H.E. Desch (Deceased)

\author{
Revised by \\ J.M. Dinwoodie \\ $\mathrm{OBE}, \mathrm{BSc}$ (For), MTech, PhD, DSc
}

Building Research Establishment

Seventh Edition

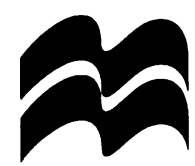


(C) H.E. Desch 1968, 1973

(C) H.E. Desch and J.M. Dinwoodie 1981

(C) J.M. Dinwoodie 1996

All rights reserved. No reproduction, copy or transmission of this publication may be made without written permission.

No paragraph of this publication may be reproduced, copied or transmitted save with written permission or in accordance with the provisions of the Copyright, Designs and Patents Act 1988, or under the terms of any licence permitting limited copying issued by the Copyright Licensing Agency, 90 Tottenham Court Road, London WIP 9HE.

Any person who does any unauthorised act in relation to this publication may be liable to criminal prosecution and civil claims for damages.

First edition 1938

Second edition 1947

Third edition 1953

Fourth edition 1968

Fifth edition 1973

Sixth edition 1981

Seventh edition 1996

Published 1996 by

MACMILLAN PRESS LTD

Houndmills, Basingstoke, Hampshire RG21 6XS

and London

Companies and representatives throughout the world

ISBN 978-0-333-60905-7

ISBN 978-1-349-13427-4 (eBook)

DOI 10.1007/978-1-349-13427-4

A catalogue record for this book is available from the British Library

$\begin{array}{rrrrrrrrrr}10 & 9 & 8 & 7 & 6 & 5 & 4 & 3 & 2 & 1 \\ 05 & 04 & 03 & 02 & 01 & 00 & 99 & 98 & 97 & 96\end{array}$

Typeset by Aarontype Limited, Bristol 
Preface to the Seventh Edition

\section{Introduction}

1.1 Consumption of timber

1.2 The tree

1.3 Classification of trees

1.4 Nomenclature of timbers

Reference xi 4 Molecular Structure

4.1 Principal chemical constituents 37

$\mathbf{1}$

4.1.1 Cellulose

4.1.2 Hemicelluloses

4.1.3 Lignin

4.2 The microfibril

4.3 The cell wall

4.4 Mineral content

4.5 Extractives

4.6 Acidity

References

\section{Part 1 STRUCTURE OF WOOD 7}

\section{Gross Structure}

2.1 The tree

2.2 Growth of the tree

2.3 Growth rings

2.4 Sapwood and heartwood

2.5 Knots

References

\section{Cellular Structure}

3.1 Differentiation and types of cells

3.2 Softwoods

3.2.1 Conducting and supporting cells

3.2.2 Storage cells

3.2.3 Resin-producing cells

3.2.4 Variability in cellular features between species 22

3.3 Hardwoods

3.3.1 Types of cells

3.3.2 Conducting cells

3.3.3 Supporting cells

3.3.4 Storage cells

3.3.5 Deposits

3.3.6 Resin canals or gum ducts

3.3.7 Latex tubes

References

27

31

32

34

35

36

36

\section{Variability in Structure}

5.1 Genetical causes of variability

5.2 Systematic sources of variability

5.3 Environmental influences

5.4 Variability due to presence of natural defects

5.4.1 Compression wood

5.4.2 Tension wood

5.4.3 Pith flecks

5.4.4 Bark pockets

5.4.5 Resin streaks (or pitch streaks)

5.4.6 Pitch pockets, seams or shakes

5.4.7 Gum veins

5.4.8 Strawberry mark

5.4.9 Mineral streaks

5.4.10 Compression creases, kinks and natural

compression failures $\quad 53$
5.4.11 Brittleheart

References

27

27

7

6 Identification of Timbers

6.1 Use of gross characteristics

6.2 Identification of hardwoods using a hand lens
37

40

40

40

41

42

42

43

43

44

44

44

45

47

47

48

50

50

50

51

51

52

52

54

55

56

56

56 
6.3 Identification using a microscope 57

6.3.1 Slide preparation 57

6.3.2 Microscopic examination 60

6.4 Keys to assist identification 61

6.4.1 Dichotomous keys 61

6.4.2 Multiple entry keys 62

6.4.3 Computer-aided wood identification

6.5 Cross-checking of identification

References
9.3 Equilibrium moisture content

87

9.4 Shrinkage

9.5 Movement

89

9.6 Dimensional stabilisation

References

\section{Other Physical Properties} of Wood

Part 2 PROPERTIES OF WOOD - INFLUENCE OF STRUCTURE

\section{Appearance of Wood}

\subsection{Texture}

7.2 Figure

7.2.1 Grain

7.2.2 Growth rings

7.2.3 Knots

7.2.4 Rays

7.3 Colour

7.4 Lustre

\section{Density of Wood}

8.1 Definition of density

8.2 Determination of density

8.2.1 Using a dry measure of volume

\subsubsection{Using volume displacement}

8.3 Variation in density of wood

8.4 Practical significance of density Reference

\section{Moisture in Wood}

9.1 Amount and location of moisture 81

9.2 Determination of moisture content

9.2.1 Oven-dry method

9.2.2 Distillation method

9.2.3 Moisture meters

\section{7}

10.1 Thermal properties of wood 96 10.1.1 Thermal conductivity 96 10.1.2 Specific heat capacity 96 10.1.3 Linear thermal expansion 97

10.1.4 Heat (calorific) value 97 10.1.5 Reaction of wood to heat

10.1.6 Reaction of wood to fire

98

10.2 Electrical conductivity

10.3 Acoustic properties of wood 100 100 10.3.1 Sound production 100 10.3.2 Sound reduction 101

References

\section{Strength, Elasticity and} Toughness of Wood

\subsection{Introduction}

102

11.2 General principles

11.3 Determining the strength

102

and elastic properties

104

11.3.1 Sample size

11.3.2 Test methods

11.4 Strength and elastic properties, and toughness

11.4.1 From small clear

$\begin{array}{ll} & \text { specimens } \\ 11.4 .2 & \text { From structural-sized }\end{array}$ 104 105

109 specimens 109

11.4.3 Reaction to stress under different modes of loading 
Contents vii

11.5 Factors influencing the strength and elasticity (stiffness) of wood

11.5.1 Density (including ring width and ratio of early wood to late wood)

11.5.2 Angle of the grain

11.5.3 Knots

11.5.4 Other anatomical features

11.5.5 Moisture content

121

121

11.5.6 Temperature

11.5.7 Time

11.5.8 Defects

11.6 Factors influencing the toughness of wood

11.6.1 Density

11.6.2 Angle of the grain

11.6.3 Knots

11.6.4 Other anatomical features

11.6.5 Moisture content

11.6.6 Temperature

11.6.7 Defects

11.7 Derivation of basic stresses from small clear test specimens

References

\section{Part 3 PROCESSING OF} TIMBER - HOW TO CUT IT UP, DRY AND GRADE IT

\section{Log Conversion}

12.1 Restrictions on conversion

12.1.1 Shape of the log

12.1.2 Growth stresses

12.1.3 Possible exclusion of sapwood

12.1.4 Possible exclusion of juvenile wood
12.2 Primary conversion equipment

134

12.2.1 Circular saws 135

12.2.2 Bandsaws 136

12.2.3 Frame saws 136

12.2.4 Chipper canters 136

12.3 Conversion of hardwood logs 137

12.4 Conversion of softwood logs 137

12.5 Computer-aided log conversion

142

12.6 Conversion factors 143

12.7 Defects 143

References $\quad 143$

\section{Seasoning of Wood}

144

13.1 Principles of seasoning

144

13.2 Air seasoning

145

13.3 Kiln seasoning

148

13.3.1 Construction of kilns 152

13.3.2 Types of kilns $\quad 152$

13.3.3 Kiln operation 153

13.4 Solar kilns 155

13.5 Radio frequency drying of wood

13.6 Seasoning defects 156

13.6.1 Types of warping 156

13.6.2 Types of rupture of the wood tissue

156

Reference

\section{Machining of Wood and} Board Materials

159

14.1 General principles

14.2 Machining equipment

14.2.1 Circular saws

160

14.2.2 Bandsaws (narrow) 160

14.2.3 Planers, routers and spindle moulders $\quad 160$

14.2.4 Sanders 161

$\begin{array}{lll}14.3 & \text { Dust } & 161\end{array}$

14.3.1 Dust levels and requirements

14.3.2 Health problems associated with wood processing

References 


\section{Timber Grading and} Grade Stresses
164

15.1 Introduction

164

15.2 Grading of softwoods

15.2.1 Appearance grading based on a 'visual defects' system

15.2.2 Stress grading

15.2.3 Strength classes

15.3 Grade stresses for softwoods

15.4 Grading of hardwoods

15.4.1 Appearance grading based on 'visual defects' or 'cutting' systems

15.4.2 Stress grading of hardwoods

15.4.3 Strength classes

15.5 Grade stresses for hardwoods References

164

164

166

169

170

173

173

177

177

177

177
179

\section{Utilisation of Timber}

181

16.1 Choice of timber

16.1.1 Selection of species

16.1.2 Specification of timber

16.2 Joining together of

timber parts

16.2.1 Adhesives

16.2.2 Joint design using adhesives

181

181

182

183

183

188

16.2.3 Joint design using metal connectors
16.3.3 Timber in transportation 204

16.3.4 Timber in packaging 205

16.3.5 Timber in mining 205

16.3.6 Timber for transmission poles 206

16.3.7 Timber in furniture 206

16.3.8 Timber in sports goods

16.3.9 Timber in musical instruments 207

209

References

\section{Manufactured Wood Products and their Applications}

211

17.1 Introduction

211

17.2 Enhancement with plastics

17.2.1 Impregnated and compressed wood 211

17.2.2 Wood-plastic composite

17.3 'Engineered structural timber' 212

17.3.1 Laminated veneer lumber (LVL)

17.3.2 Parallel strand lumber (PSL)

17.3.3 Laminated strand lumber (LSL)

213

17.3.4 'Scrimber'

17.4 Board materials (wood-panel products)

17.4.1 Plywood

17.4.2 Chipboard (particleboard)

17.4.3 OSB (Oriented strand board)

16.3 Examples of timber utilisation

16.3.1 Timber in construction

16.3.2 Timber in marine work 
Part 5 TIMBER IN SERVICE

- WHAT HAPPENS TO

WOOD IN SERVICE?

- HOW CAN ITS LIFE

BE EXTENDED?

18 Degradation of Timber

233

18.1 Introduction

18.2 Biological degradation

233

18.3 Chemical degradation

18.4 Photochemical degradation

18.5 Thermal degradation

18.6 Degradation by fire

18.7 Mechanical degradation

References

231

233

233

234

235

235

236

237
20.4 Other timber beetles

258

20.5 Termites

258

20.6 Marine borers

260

References in Service

19.1 General principles 238

19.2 Wood-rotting fungi

239

19.2.1 Standing tree fungi 240

19.2.2 Log and timber fungi 240

19.2.3 Fungi that attack wood in service

19.3 Sap-stain fungi

242

246

References

248

20 Worm in Timber

249

20.1 Forest and mill-yard pests

249

20.1.1 Longhorn beetles

249

20.1.2 Pin-hole borers (ambrosia beetles) 250

20.2 Pests of seasoning yards

251

20.2.1 Lyctus or powder-post beetles 251

20.2.2 Bostrychid powder-post beetles 253

20.3 Pests of well-seasoned wood 254

20.3.1 Common furniture beetle

20.3.2 Death-watch beetle 255

20.3.3 House longhorn beetle
22 Preservation of Timber

22.1 General principles

271

22.2 Properties of preservatives

22.3 Testing and approval of preservatives

\section{Eradication of Fungal and Insect Attack}

262

21.1 Eradication of fungal decay

263

21.2 Eradication of insect infestation

266

270

271

22.4 Classes of wood preservatives 272

22.4.1 Tar oil group of preservatives

22.4.2 Water-borne

$\begin{array}{ll} & \text { preservatives } \\ 22.4 .3 & \text { Organic solven }\end{array}$

271

272

273 wood preservatives

273

274

22.4.4 Other preservative types

22.5 Application of wood preservatives

275

22.5.1 High pressure/

275

vacuum processes

276

22.5.2 Double vacuum process

277

22.5.3 Diffusion with aqueous solutions $\quad 277$

22.5.4 Immersion treatment 278

22.5.5 Brushing, spraying and deluging

278

22.5.6 Hot and cold open-tank process 278

22.5.7 Sap displacement method 279

22.5.8 Treatment with limited resources

279 
x Contents

22.5.9 Drying of treated timber

279

22.5.10 Retreatment of cut surfaces

22.6 Health and safety

22.7 Properties of treated timber

22.7.1 Strength

22.7.2 Corrosion of metal fasteners and fittings 280

22.7.3 Surface finishes

22.8 Validation of treatments

22.9 European standards

22.10 Flame-retardant solutions

References

\section{Wood Finishes}

23.1 Introduction

23.2 Paint systems

23.2.1 Conventional paints ('general purpose')

280

281

282

284

284

284 285
23.3 Natural finishes for exterior wood 286

23.3.1 Exterior wood stains 286

23.3.2 Varnishes

287

23.3.3 Oils 287

23.3.4 Preservatives 287

23.4 Finishes for wood floors 287

23.5 Flame-retardant coatings 287

References

288

Selected Bibliography - additional to that

281 listed at the end of most chapters

289

Appendix I: List of Botanical Equivalents of Common or Trade Names used in the Text

291

Appendix II: Table of Conversion Factors

295

Appendix III: Trade Organisations in the UK with Responsibility for Certain Products

296

23.2.2 Special exterior paints 285 Index 


\section{Preface to the Seventh Edition}

Dr H.E. Desch died in 1978 after a lifetime of service devoted to the acquisition and critical appraisal of knowledge on all aspects of timber technology, and to its subsequent dissemination by publication of this text together with its practical application through his consultancy. The first edition of this book was published in 1938 and the first revision in 1947. Since then it has been revised at regular intervals, continuing to fulfil the needs of students in timber technology for an authoritative and comprehensive text on the subject.

Dr Desch was about to embark on the sixth edition when he died, and I was subsequently approached to undertake that revision: this I was pleased to do and the sixth edition was published in 1981. Since then the knowledge of wood science has increased, new European Standards have replaced many British Standards, new grading techniques have become established, and new board materials have appeared on the market, to illustrate but a few of the many changes in wood technology. I was invited in 1993 to again revise the text: in agreeing to accept the challenge, I have again found this to be no light task. Indeed, the amount of new information that has had to be incorporated has resulted in an almost total rewrite of the text. The opportunity has been taken not only to rearrange certain topics to bring these into line with current thinking, but also to widen the scope of the book to cover areas of conversion, machining, and the application of paints and finishes, thereby making the text even more comprehensive; this in line with the many helpful comments received.

The text is divided into 23 chapters which are ascribed to five parts covering the Structure of Wood; Properties of Wood; Processing of Timber; Utilisation of Timber; and Timber in Service.

In Part 1, the chapters on structure have been updated and revamped. Separate chapters now deal with structure at the gross, cellular and molecular levels. Variability in structure is comprehensively covered in a further chapter, enlarged not only to deal with aspects previously covered in other chapters, but also to embrace new areas of variability in structure. Identification in structure has been enlarged to include section preparation. Regrettably, there have had to be losses as well as gains: feedback has indicated a much reduced need for timber descriptions and, since this subject is covered in many other handbooks, these have now been deleted.

In Part 2 of the text, the properties of wood are dealt with comprehensively in a set of five chapters, the last of which, on mechanical performance, has been enlarged to cover elastic behaviour, toughness and the use of structural-sized timber for strength tests.

Part 3, dealing with timber processing, covers many new areas not discussed in previous editions. Thus, the conversion of the tree to timber is described in terms of those properties and variables of wood that influence its conversion to usable timber. A second chapter covering the seasoning of timber describes not only traditional air- and kiln-drying, but also deals with solar and high temperature drying. A third chapter contains new information on the machining of timber with emphasis on health and safety. The grading of timber has undergone major changes since the previous revision and these are described: parallel changes have taken place in the derivation of grade stresses (and characteristic values) during this period and this subject is treated in much detail.

Part 4 is concerned with the utilisation of timber and board materials. New boards and structural composites have emerged since the last revision and the chapter on board materials has been extensively updated and enlarged. The British Standards on wood adhesives have been replaced with the new European Standards. 
Part 5 is devoted to all aspects of timber in service, commencing with a new and generalised chapter on degradation, followed by a series of specialised chapters on fungal attack, insect attack and their eradication. This part concludes with preventative measures covering preservation and the application of finishes.

In view of this more comprehensive treatment of timber, it is no longer possible for any one individual to write authoritatively on every aspect of timber technology, embracing as it does structure, properties, conversion, utilisation and behaviour in service. Therefore, I am deeply indebted to a number of my colleagues in coming to my assistance and giving so willingly of their own free time to assist in a wide variety of ways, all of which are deeply appreciated.

I am particularly indebted to Mr Roger Berry in charge of the Biodeterioration Section, Building Research Establishment for completely revising Chapters 20 (insects) and 21 (eradication); to Dr Janice Carey of the BRE Biodeterioration Section for the revision of Chapter 19 (fungi); and to Dr Reginald Orsler in charge of the Preservation Section, BRE for the revision of Chapter 22 on the preservation of timber.

Several of my colleagues or former colleagues at BRE have spent many hours of their free time reading my first draft and making the most valuable of comments and suggestions: in particular I would like to thank Keith Maun, Head of the BRE Utilisation Section (Chapters 12 - log conversion, 13 - seasoning and 14 - machining); Clive
Benham (Chapter 15 - grading); Gerald Moore (Chapter 6-identification); Peter Bonfield (Chapters 9 - moisture, 11 - strength, 16 - utilisation and 18-degradation); John Boxall (Chapter 23 - finishes); and John Brazier, former Head of Wood Properties section (Chapters 1 introduction and 3 - cellular structure). I would also like to thank Mr E. van der Strataen for his guidance and valuable comments on the adhesives section of Chapter 16 (utilisation).

My very sincere gratitude is extended to Mrs Sue Phillips, Mrs Margaret Penney, Mrs Hilda Ridgewell and Mrs Jo Mundy for the many hours of their own time spent in word processing my scrawl, and in the subsequent updating of the text following receipt of comments. I am greatly indebted to both Mrs Jo Mundy and Dr Peter Bonfield who, between them, have read the entire draft text in their own time, thus reducing very considerably the number of errors in the published book.

I would also like to express my appreciation to the Chief Executive of BRE, Mr Roger Courtney, for permission to use a considerable number of illustrations from the former Princes Risborough Laboratory, now within the guardianship of the Building Research Establishment.

Lastly, I would like to extend my gratitude and appreciation to my wife, who has been so helpful, patient and understanding over the last nine months and who has spent many hours reading the proofs with me.

Princes Risborough, 1996

J.M.D. 